Pathobiochemistry

\title{
Fluoride affects bone repair differently in mice models with distinct bone densities
}

\author{
Paula Kennerly Herrera ${ }^{a}$, Andressa Pelissari Zambolin ${ }^{a}$, Mileni da Silva Fernandes ${ }^{b}$, \\ Tânia Mary Cestari a , Flávia Godoy Iano ${ }^{a}$, Willian Fernando Zambuzzic ${ }^{c}$, \\ Marília Afonso Rabelo Buzalaf ${ }^{a}$, Rodrigo Cardoso de Oliveira ${ }^{a, *}$ \\ a Department of Biological Sciences, Bauru School of Dentistry, University of São Paulo, Al. Octávio Pinheiro Brisolla, 9-75, 17012-901, Bauru, São Paulo, \\ Brazil \\ ${ }^{\mathrm{b}}$ Department of Genetics and Evolution, Center of Biological Sciences and Health, Federal University of São Carlos, Washington Luis, km 235, 13560-970, \\ São Carlos, São Paulo, Brazil \\ ${ }^{\mathrm{c}}$ Laboratory for Bioassays and Cellular Dynamics, Department of Chemistry and Biochemistry, Bioscience Institute, São Paulo State University, Rubião \\ Junior S/N, 18618-970, Botucatu, São Paulo, Brazil
}

\section{A R T I C L E I N F O}

\section{Article history:}

Received 1 July 2016

Received in revised form 23 August 2016

Accepted 13 September 2016

\section{Keywords:}

Bone repair

Fluoride

Mouse

Bone tissue

\begin{abstract}
A B S T R A C T
We grouped mice [strains: $\mathrm{C} 57 \mathrm{BL} / 6 \mathrm{~J}(n=32)$ and $\mathrm{C} 3 \mathrm{H} / \mathrm{HeJ}(n=32)$ ] to address the influence of bone density on fluoride's (F's) biological effects. These animals received low-fluoride food and water containing 0 (control group) or $50 \mathrm{ppm}$ of $\mathrm{F}$ for up to 28 days. The upper left central incisor was extracted, and the left maxilla was collected at 7, 14, 21, and 28 days for histological and histomorphometric analysis to estimate bone neoformation. Our results showed bone neoformation in all of the evaluated groups, with the presence of bone islets invading the center of the alveoli when replacing the existing connective tissue. Curiously, this biological phenomenon was more evident in the C57BL/6J strain. The histomorphometric analysis confirmed the histological findings in relation to the amount of new bone tissue and showed a decrease in $\mathrm{C} 3 \mathrm{H} / \mathrm{HeJ}$ mice (control group). Altogether, our results showed differential effects of fluoride bone metabolism, confirming a genetic component in susceptibility to the effects of fluoride.
\end{abstract}

(c) 2016 Elsevier GmbH. All rights reserved.

\section{Introduction}

Repairing bone loss due to various diseases such as osteoporosis and tumor resection has been a great challenge within regenerative medicine. Because of its importance, several groups worldwide have investigated strategies and biological molecules for bone repair, such as BMPs [1,2] and fluoride (F) [3-5]. In this way, fluoride is known to be deposited in calcified tissues [6]; however, the biological effects of fluoride on bone repair and its effects on bone cells remain unknown $[7,8]$. Bone cells may have a dose-dependent response to fluoride, which may stimulate bone formation at a low dose or be toxic at a high dose [9,10].

Fluoride's action profiles in alveolar bone repair models would provide information about the chronological evolution of the repair process and the main cellular events at each stage [11]. Biomechanical bone studies performed on different strains of mice have reported differences in bone mass and the capacity of

\footnotetext{
* Corresponding author.

E-mail address: rodrigocardoso@usp.br (R.C.d. Oliveira).
}

differentiation in osteoblasts [12-14]. In addition, we have shown the preliminary effects of fluoride on the bone-repairing process in vivo [15,16] and on osteoblasts [17].

In order to address fluoride's effects on bone metabolism during alveolar bone repair, we decided to comparatively evaluate two strains of mice (C57BL/6J and $\mathrm{C} 3 \mathrm{H} / \mathrm{HeJ}$, presenting differential physiological bone masses) by using histomorphometric analysis. In sum, our results showed a differential effect of fluoride on bone metabolism, confirming a genetic component in susceptibility to fluoride's effects.

\section{Materials and methods}

\subsection{Animals}

All experimental procedures were performed according to "The Guiding Principles for the Care and Use of Animals" and the ARRIVE guidelines. The protocol was approved by the Animal Experimentation Committee of University of São Paulo (Process \#07/2010). Weanling (21 days old) male C57BL/6J $(n=32)$ and C $3 \mathrm{H} / \mathrm{HeJ}(n=32)$ mice were obtained from the Central Vivarium of Bauru Dental 
School (University of São Paulo), randomly distributed into four groups, and given a low-F diet and water containing either 0 or $50 \mathrm{ppm}$ of $\mathrm{F}$ added as NaF. The mice were housed in conventional plastic cages with metal bars and artificial lighting, with a photoperiod of $12 \mathrm{~h}$ light $/ 12 \mathrm{~h}$ dark and regulated temperature and humidity. After 60 days of treatment, the animals were subjected to surgical procedures. During the entire study (pre-and postsurgery), the animals had free access to drinking water ( 0 or $50 \mathrm{ppm}$ of F) and food.

\subsection{Surgical procedures and treatments}

To evaluate alveolar bone repair in different conditions, the animals (total $n=64$ ) were divided into 4 experimental groups, as follows: 1. $\mathrm{C} 3 \mathrm{H}-0 \mathrm{ppm}$ : $\mathrm{C} 3 \mathrm{H} / \mathrm{HeJ}$ mice that received deionized water $(n=16) ; 2$. $\mathrm{C} 3 \mathrm{H}-50 \mathrm{ppm}$ : $\mathrm{C} 3 \mathrm{H} / \mathrm{HeJ}$ mice that received water with $50 \mathrm{ppm}$ of fluoride $(n=16) ; 3$. B6-0 ppm: $\mathrm{C} 57 \mathrm{BL} / 6 \mathrm{~J}$ mice that received deionized water $(n=16)$; and 4 . B6-50 ppm: C57BL/6J mice that received water with $50 \mathrm{ppm}$ of fluoride $(n=16)$. Firstly, the animals received an intramuscular injection of xylazine chlorhydrate for muscular relaxation and were anesthetized with ketamine chlorhydrate (1:1), with a dose determined according to body weight [18]. The upper left central incisor was extracted [16], and at the end of the experimental periods of $7,14,21$, and 28 days, the animals were euthanized with an anesthetic overdose and the left maxilla was removed for histological/histomorphometric analysis.

\subsection{Histology and histomorphometry}

After each experimental period group, the samples ( $n=4 /$ period/group) were collected and immediately fixed in phosphate-buffered formaldehyde (10\%) for $48 \mathrm{~h}$ and then subjected to demineralization by using $0.05 \mathrm{M}$ ethylenediaminetetraacetic (EDTA), pH 7.4 [19]. Then, the samples were dehydrated with graded ethanol, diaphanized in xylene, and embedded in Histosec (Merck KGaA), according to the classical steps of the histological procedure. Transversal $4 \mu \mathrm{m}$-thick semi-serial sections were created in a microtome (Microm, model HM 340 E, Germany), and representative sections were mounted on glass slides for hematoxylin/eosin staining.

The microscopic images required an Olympus SC30-CCD camera (Olympus, Hamburg, Germany) mounted on an Olympus System Microscope Model BX43 to take, which were then processed with CellSens software (Olympus, Hamburg, Germany). Quantitative histomorphometry was used to evaluate the formation/resorption of blood clots and the formation of granulations, connective tissue, and new bone. Thereafter, the total surface area $\left(\mu \mathrm{m}^{2}\right)$ of each alveolus and the setting areas with new bone formation, connective tissue, and other tissues (blood clot) or structures were measured. The data (areas: new bone and connective tissue) were converted into percentages (\%). For better analysis and description, the hemimaxilla (dental alveolus) was divided into and analyzed as cervical, middle, and apical thirds.

\subsection{Statistical analysis}

Comparative statistical analyses-specifically, ANOVA and the Tukey test-were applied using Prism GraphPad 5.0 (Prism software, GraphPad, USA). The level of significance was $5 \%$ for all cases.

\section{Results}

\subsection{Histological findings}

All of mice tolerated the surgical procedure well. There were no complications, and all of the animals could be euthanized as planned. No reductions were observed in body weight, nor were signs of postoperative infections observed.

For the histological analysis, we described the total dental alveolus, i.e., all of the thirds (cervical, middle, and apical) in all of the groups during the different experimental periods. During the 7-day period, for all of the groups, we observed the abundant presence of connective tissue in the alveolar center (Fig. 1A), newly formed bone tissue growing on the walls toward the center (Fig. 1B), and blood vessels distributed at various sites. At 14 days, a similar scenario was observed in both the $\mathrm{C} 3 \mathrm{H}$ and $\mathrm{B} 6$ groups: the connective tissue occupied a smaller space (Fig. 1C). New bone was observed in the alveolar walls, as was bone formation forming islets toward the center. However, we found a distinct formation in the B6-0 ppm group (Fig. 1D), with the islets of bone formation arranged along the alveoli. In general, for the $\mathrm{C} 3 \mathrm{H}$ and $\mathrm{B} 6$ groups during the 21-day period, the alveolus was occupied by new bone tissue (trabecular) and connective tissue present between the trabecular bone (Fig. 2A, B). During the last period (28 days), bone neoformation occupied a larger area of the alveoli, with the same pattern formation in all of the groups. In addition, we observed a decrease in connective tissue (Fig. 2C and D). It is relevant to mention that some of the samples presented small pieces of tooth root.

\subsection{Histomorphometric analysis}

Histomorphometric analysis was performed on the alveolar thirds, as recommended by Accorsi-Mendonça et al. [20] and Vieira et al. [16]. All of the cited data are shown in Tables $1-3$. Some minor areas such as blood clots, small pieces of tooth root, and "technical artifacts" were not included in the tables.

\subsubsection{Cervical third}

The B6 strain showed higher bone formation according to the period (from $38.63 \%$ to $51.42 \%$ for the control and $26.83 \%$ to $56.72 \%$, $50 \mathrm{ppm}$ ). The most significant amount was during the 21-day period $(52.40 \pm 1.44 \%$ for B6, 0 ppm, $53.86 \pm 2.97 \%$ for B6, 50 ppm; $\mathrm{p}<0.05)$. Similar amounts of bone tissue formed among the periods in all of the tested groups. Most of the groups showed a gradual formation of bone tissue during the studied periods, but less new bone formed during the $\mathrm{C} 3 \mathrm{H}, 50 \mathrm{ppm}$ group at 28 days $(39.07 \pm 14.91 \%$ for $\mathrm{C} 3 \mathrm{H}, 0 \mathrm{ppm}, 34.85 \pm 4.07 \%$ for $\mathrm{C} 3 \mathrm{H}, 50 \mathrm{ppm}$ ), although this was not significant. Connective tissue decreased gradually during all of the periods, except in the $\mathrm{C} 3 \mathrm{H}, 50 \mathrm{ppm}$ group during the 28-day period. In general, the $\mathrm{B} 6$ strain presented less connective tissue than the $\mathrm{C} 3 \mathrm{H}$ strain.

\subsubsection{Middle third}

The patterns of gradual bone tissue formation were similar among the periods, except for the 28-day period in the $\mathrm{C} 3 \mathrm{H}$ strain. The B6 strain had major formation of new bone tissue (42.3\%), which was gradual in both groups (0 and $50 \mathrm{ppm})$, with major formation in the $\mathrm{B} 6-50 \mathrm{ppm}$ group when compared with the $\mathrm{C} 3 \mathrm{H}-$ $50 \mathrm{ppm}$ group, such as in the 21-day and 28-day periods (Table 2). Consequently, due to the increased bone formation in the B6 strain, a smaller amount of connective tissue was found in this strain compared to in the $\mathrm{C} 3 \mathrm{H}$ strain. Finally, we observed that the $\mathrm{B} 6$, $50 \mathrm{ppm}$ group presented a gradual decrease by period, with the 28-day period presenting the lowest amount of connective tissue, compared with the other groups ( $48.35 \pm 5.68 \%)$.

\subsubsection{Apical third}

This region showed the smallest amount of new bone formation. The groups that received $50 \mathrm{ppm}$ of $\mathrm{F}$ presented major formations of bone tissue, especially in the 7-and 21-day periods for the B6 strain. However, at 28 days for this same strain, we observed lower bone 


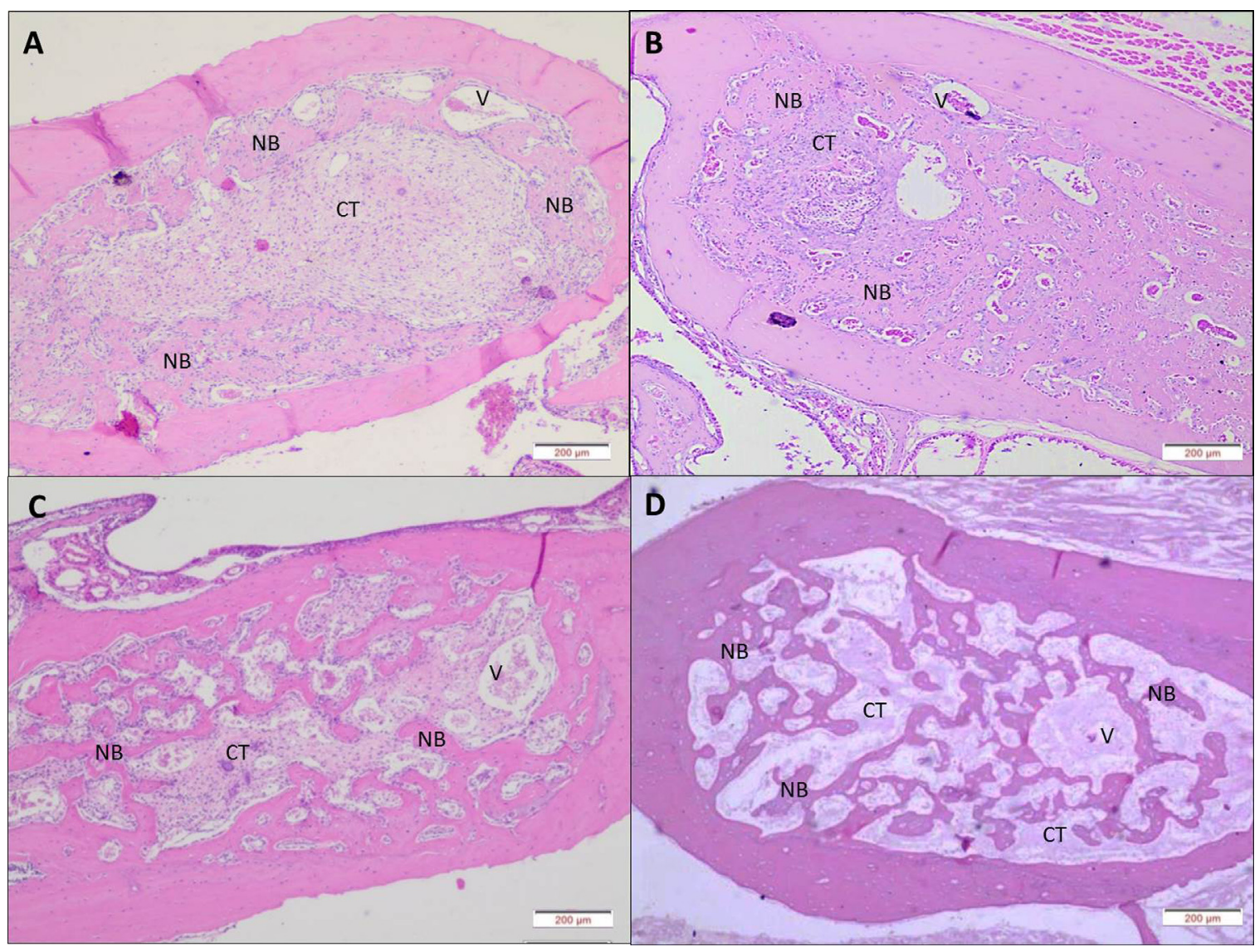

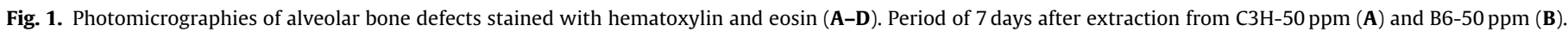
Period of 14 days after extraction from $\mathrm{C} 3 \mathrm{H}-0 \mathrm{ppm}(\mathbf{C})$ and B6-0 ppm (D). Note: NB: new bone; CT: connective tissue; V: blood vessel.

Table 1

Bone tissue areas (\%) and connective tissue formed in alveoli's cervical third.

\begin{tabular}{|c|c|c|c|c|c|c|c|c|}
\hline \multirow[t]{3}{*}{ PERIODS (days) } & \multicolumn{8}{|c|}{ GROUPS } \\
\hline & \multicolumn{2}{|l|}{$\mathrm{C} 3 \mathrm{H}-0 \mathrm{ppm}$} & \multicolumn{2}{|l|}{ С $3 \mathrm{H}-50 \mathrm{ppm}$} & \multicolumn{2}{|l|}{ B6-0 ppm } & \multicolumn{2}{|l|}{ B6-50 ppm } \\
\hline & BT & $\mathrm{CT}$ & BT & $\mathrm{CT}$ & BT & $\mathrm{CT}$ & BT & $\mathrm{CT}$ \\
\hline 7 & $26.56 \pm 7.93$ & $69.11 \pm 15.70$ & $30.02 \pm 7.41$ & $69.98 \pm 7.91$ & $38.63 \pm 15.00$ & $59.66 \pm 12.73$ & $26.83 \pm 17.22$ & $73.17 \pm 20.73$ \\
\hline 14 & $29.08 \pm 3.17$ & $70.92 \pm 5.27$ & $31.18 \pm 5.38$ & $65.75 \pm 12.27$ & $33.74 \pm 2.53$ & $66.26 \pm 3.73$ & $33.03 \pm 4.04$ & $66.97 \pm 5.02$ \\
\hline 21 & $37.63 \pm 6.89$ & $62.37 \pm 7.09$ & $38.41 \pm 11.95$ & $61.48 \pm 12.12$ & $52.40 \pm 1.54^{\mathrm{a}}$ & $47.60 \pm 2.02$ & $53.86 \pm 4.11$ & $46.14 \pm 2.97$ \\
\hline 28 & $39.07 \pm 14.91^{c}$ & $60.93 \pm 13.01$ & $34.85 \pm 4.07$ & $65.15 \pm 5.15$ & $51.42 \pm 9.33$ & $48.58 \pm 8.98$ & $56.72 \pm 5.33^{b}$ & $43.28 \pm 4.50$ \\
\hline
\end{tabular}

Mean \pm SD. BT bone tissue, $C T$ connective tissue.

a Significant difference, among same period groups and same strains.

b Significant difference, same period and between groups treated with fluoride.

c Significant difference, same period, between strains treated or not with fluoride.

formation in the group receiving $50 \mathrm{ppm}(42.49 \pm 7.64 \%$ for B6$0 \mathrm{ppm}, 18.80 \pm 2.02 \%$ for $\mathrm{B} 6-50 \mathrm{ppm}$ ). This same group showed the lowest amount of connective tissue ( $37.72 \pm 6.73 \%$ for $\mathrm{B} 6-50 \mathrm{ppm})$. Altogether, these results suggest that fluoride is a biological mediator for decreasing the amount of connective tissue and replacing it with new bone formation in the B6 strain (7 days: $69.68 \pm 2.05 \%$; 28 days: $37.72 \pm 6.73 \%, p>0.05)$, which did not happen in the $\mathrm{C} 3 \mathrm{H}$ strain ( 7 days: $74.70 \pm 0.17 \%$; 28 days:

Table 2

Areas (\%) of bone tissue and connective tissue formed in alveoli's middle third.

\begin{tabular}{|c|c|c|c|c|c|c|c|c|}
\hline \multirow[t]{3}{*}{ PERIODS (days) } & \multicolumn{8}{|c|}{ GROUPS } \\
\hline & \multicolumn{2}{|l|}{$\mathrm{C} 3 \mathrm{H}-0 \mathrm{ppm}$} & \multicolumn{2}{|l|}{$\mathrm{C} 3 \mathrm{H}-50 \mathrm{ppm}$} & \multicolumn{2}{|l|}{ B6-0 ppm } & \multicolumn{2}{|l|}{ B6-50 ppm } \\
\hline & BT & $\mathrm{CT}$ & BT & $\mathrm{CT}$ & BT & $\mathrm{CT}$ & BT & $\mathrm{CT}$ \\
\hline 7 & $24.39 \pm 14.05$ & $75.61 \pm 16.26$ & $30.75 \pm 9.45$ & $65.75 \pm 10.30$ & $27.22 \pm 19.97$ & $61.77 \pm 8.90$ & $37.39 \pm 2.55$ & $62.61 \pm 3.59$ \\
\hline 14 & $35.59 \pm 2.98$ & $64.41 \pm 3.58$ & $33.45 \pm 2.93$ & $66.55 \pm 4.03$ & $35.06 \pm 4.53$ & $64.94 \pm 5.05$ & $42.74 \pm 5.89$ & $57.26 \pm 6.22$ \\
\hline 21 & $45.00 \pm 9.87$ & $55.00 \pm 10.44$ & $43.87 \pm 7.95$ & $53.03 \pm 5.07$ & $46.42 \pm 6.38$ & $48.96 \pm 7.39$ & $50.24 \pm 9.03$ & $49.76 \pm 8.60$ \\
\hline 28 & $27.16 \pm 5.80$ & $62.25 \pm 14.55$ & $29.94 \pm 3.47$ & $70.06 \pm 4.09$ & $47.77 \pm 6.89$ & $52.23 \pm 7.29$ & $51.65 \pm 5.68$ & $48.35 \pm 5.05$ \\
\hline
\end{tabular}

Mean \pm SD. BT bone tissue, $\mathrm{CT}$ connective tissue. 


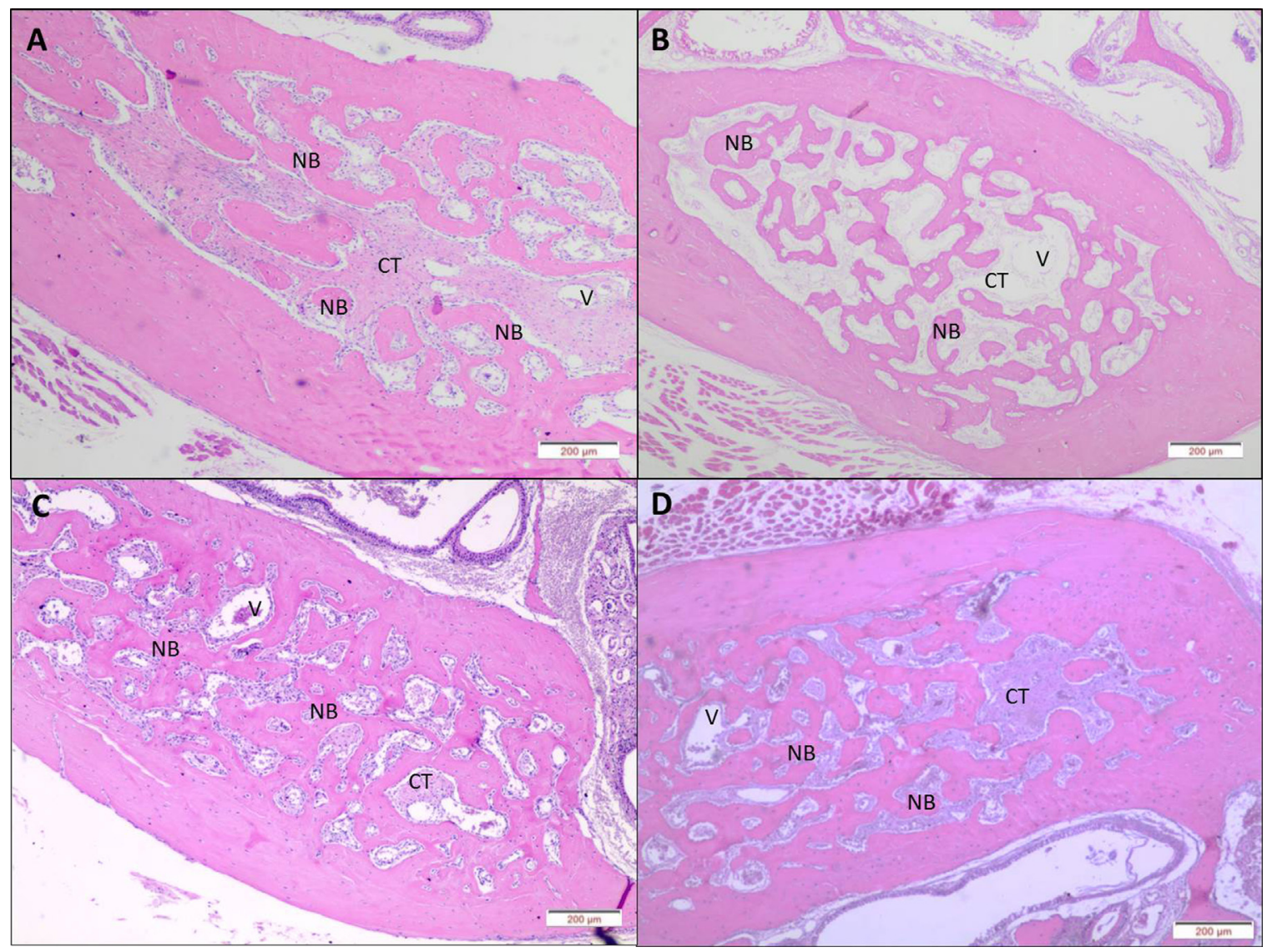

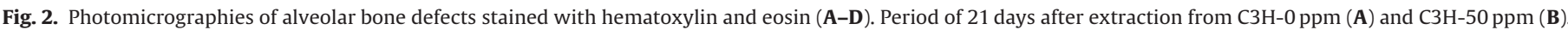
Period of 28 days after extraction from B6-0 ppm (C) and B6-50 ppm (D). Note: NB: new bone; CT: connective tissue; V: blood vessel.

$74.42 \pm 1.75 \%)$. Moreover, the results showed that the B6 strain generally had the lowest amount of connective tissue, compared with $\mathrm{C} 3 \mathrm{H}$.

\section{Discussion}

The dose of $50 \mathrm{ppm}$ of fluoride was selected for this study because rodents metabolize fluoride 10 times faster than humans [21]. This means that when rodents ingest water containing $50 \mathrm{ppm}$ fluoride, their plasma fluoride levels are expected to be similar to those of humans that are ingesting water containing $5 \mathrm{ppm}$ fluoride. This concentration can be naturally found in the drinking water of areas of endemic fluorosis $[6,21,22]$.

About $79 \%$ of the variability in familial bone density is based on individual genetics [12]. In the last several years, the genetic diversity of mice in inbred strains has yielded phenotypes relevant to human health, such as for susceptibility to cancer, aging, and obesity, among others $[9,23]$. Specially, both C3H and B6 mice strains are models used for studying the biomechanic properties of the skeleton, since they physiologically present larger and smaller body masses, respectively [12]. Based on this mice model for studying bone metabolism and the necessity of investigating the effects of fluoride metabolism in living systems, we decided to investigate alveolar bone repair in mice treated with 2 concentrations of fluoride, compared with control groups in which the animals were maintained without fluoride. In this biological model, the $\mathrm{C} 3 \mathrm{H}$ strain represents an organism with normal bone density and B6 is an organism presenting bone loss, a phenomenon that occurs in osteoporosis disease as well.

We observed the repairing phases of alveolar bone during the studied periods, which were consistent with other findings that describe alveolar bone repair [16,20,24]. When comparing bone repair in different strains, we observed that the $\mathrm{C} 3 \mathrm{H}$ strain showed a pattern of bone formation that restricted the nearby walls of the alveoli, forming dense trabecular bone. On the other hand, in mice from the B6 strain, the newly formed trabecular bone advanced toward the center of the alveoli, forming thinner trabecular bones with connective tissue among them. These bone

Table 3

Areas (\%) of bone tissue and connective tissue formed in alveoli's apical third.

\begin{tabular}{|c|c|c|c|c|c|c|c|c|}
\hline \multirow[t]{3}{*}{ PERIODS (days) } & \multicolumn{8}{|c|}{ GROUPS } \\
\hline & \multicolumn{2}{|l|}{$\mathrm{C} 3 \mathrm{H}-0 \mathrm{ppm}$} & \multicolumn{2}{|l|}{$\mathrm{C} 3 \mathrm{H}-50 \mathrm{ppm}$} & \multicolumn{2}{|l|}{ B6-0 ppm } & \multicolumn{2}{|l|}{ B6-50 ppm } \\
\hline & BT & $\mathrm{CT}$ & BT & $\mathrm{CT}$ & BT & $\mathrm{CT}$ & BT & $\mathrm{CT}$ \\
\hline 7 & $26,44 \pm 10,19$ & $71,82 \pm 9,08$ & $25,30 \pm 2,17$ & $74,70 \pm 5,25$ & $12,31 \pm 1,60$ & $65,54 \pm 0,06$ & $30,32 \pm 2,05$ & $69,68 \pm 3,85$ \\
\hline 14 & $21,85 \pm 6,51$ & $78,15 \pm 7,11$ & $26,97 \pm 5,45$ & $73,03 \pm 6,54$ & $39,44 \pm 27,05$ & $60,56 \pm 32,06$ & $27,89 \pm 5,49$ & $61,77 \pm 12,79$ \\
\hline 21 & $24,93 \pm 3,49$ & $75,07 \pm 4,08$ & $31,47 \pm 10,41$ & $68,53 \pm 11,54$ & $22,08 \pm 17,06$ & $57,89 \pm 7,97$ & $44,24 \pm 6,63$ & $54,38 \pm 6,56$ \\
\hline 28 & $21,04 \pm 7,47$ & $66,30 \pm 13,24$ & $25,58 \pm 1,75$ & $74,42 \pm 4,53$ & $42,49 \pm 7,64$ & $57,51 \pm 8,42$ & $18,80 \pm 2,02$ & $37,72 \pm 6,73$ \\
\hline
\end{tabular}

Mean \pm SD. BT bone tissue, $C$ T connective tissue. 
architecture characteristics are consistent with studies described above $[25,26]$ and prove the physiological differences between the mice strains explored in this study. The difference in bone density between the strains could be the result of osteoblastic activity $[13,14]$, as the basal response of mice osteoblasts in a C3H with 32 weeks of age equals the activity of B6 mice with 16 weeks [27]. Another point, discovered recently, is the difference in the gene expression (or genetic background) [28] of these two strains [29] and the hormonal secretion affected by fluoride in both strains [30]. Current literature shows that fluoride has several effects, especially on dental fluorosis [30,31], bone metabolism [28], antioxidant systems [32], and hormonal secretions [29]. Bone has been studied as a tissue for acute or chronic expositing of fluoride, due to fluoride's affinity for mineralized tissues [33-35]. Thus, studies have highlighted the direct influence of fluoride on osteoblast activity [36-39], on collagen expression [17,40] and on size of hydroxyapatite (length and width) formed in bone [28].

In this context, by using a classical biological model for bone repair-bone alveolar repair-we showed that treatment with fluoride influenced alveolar bone repair in both of the studied strains ( $\mathrm{C} 3 \mathrm{H}$ and $\mathrm{B} 6)$, promoting a modulation of bone formation in the different thirds. The differences promoted by fluoride were more pronounced in the B6 strain in the cervical third, and this strain presented minor bone density. In vitro experiments using the same strains, treated with different concentrations of fluoride, showed changes in bone markers, especially in the B6 strain, while the $\mathrm{C} 3 \mathrm{H}$ strain showed minor changes or was unchanged $[17,41]$. Experiments testing the response of these strains to stimuli and mechanical forces to maximize bone formation described a decreased response in the $\mathrm{C} 3 \mathrm{H}$ strain $[42,43]$. Therefore, the $\mathrm{C} 3 \mathrm{H}$ strain is more "stable" or "resistant" to factors/agents that can modify bone metabolism. In our study, almost all fluoride groups had an increasing percentage of newly formed bone tissue up to 21 days, which became reduced at 28 days. In a study on using fluoride to treat osteoporosis, elderly patients who received high doses of fluoride obtained progressive increases in bone tissue during the first 40 weeks, although this value decreased sequentially. According to the authors, this decrease could be explained by the action of fluoride on quiescent cells lining the bone surfaces, differentiating them into osteoblasts or becoming replaced by new osteoblasts during the first periods [3]. The genetic influence on fluoride response was described previously by some authors [9,17,28,30,31]. Especially about mineralized tissues, we know that there are strains (mice) more "sensitive" and "resistant" for fluoride [17,31]. But they are not similar to enamel and bone response [17,30,31]. This aspect (genetic background) could be involved on alveolar bone repair, and associated of the differences found in the present study.

Mousny et al. [28] described fluoride effects in mineralization of bones, with focus in hydroxyapatite. These authors showed possible chemical and physical alterations in the hydroxyapatite structure caused by fluoride. But these alterations were not similar to all strains of mice [28]. Again, the genetic factors may contribute to the variation in response to fluoride exposure, confirming our results.

Our study supports the metabolic difference in bone tissue from different animals (B6 and $\mathrm{C} 3 \mathrm{H}$ strains) and consequently in alveolar bone repair. In addition to demonstrating a differential effect of fluoride in strains, the effects are more expressive in the B6 strain, confirming a genetic component in susceptibility to fluoride.

\section{Conflicts of interest}

The authors declare that there are no conflicts of interest regarding the publication of this paper.

\section{Authors' contributions}

Study design: Marília AR Buzalaf and Rodrigo C Oliveira; Study conduct: Paula K Herrera, Andressa P. Zambolin and Tânia M. Cestari; Data collection and analysis: Paula K Herrera, Andressa P. Zambolin, Mileni S Fernandes and Tânia M. Cestari; Data interpretation: Willian F Zambuzzi, Flávia G Iano, Marília AR Buzalaf and Rodrigo C Oliveira; Drafting manuscript: Paula K Herrera and Mileni S Fernandes; Revising manuscript content: Willian F Zambuzzi, Flávia G Iano and Rodrigo C Oliveira; Approving final manuscript: Willian F Zambuzzi, Flávia G Iano and Rodrigo C Oliveira.

\section{Acknowledgments}

The authors thank Danielle Santi Ceolin and Patrícia de Sá Mortágua Germino (Laboratory of Histology) for their technical collaboration. This study was supported by FAPESP (Grant numbers: \#2011/01425-0 and \#2012/02229-2).

\section{References}

[1] J.M. Granjeiro, R.C. Oliveira, J.C. Bustos-Valenzuela, M.C. Sogayar, R. Taga, Bone morphogenetic proteins: from structure to clinical use, Braz. J. Med. Biol. Res. 38 (10) (2005) 1463-1473.

[2] A.C. Carreira, W.F. Zambuzzi, M.C. Rossi, R. Astorino Filho, M.C. Sogayar, J.M. Granjeiro, Bone Morphogenetic Proteins: promising molecules for bone healing, bioengineering, and regenerative medicine, Vitam. Horm. 99 (2015) 293-322.

[3] R. Balena, M. Kleerekoper, J.A. Foldes, M.S. Shih, D.S. Rao, H.C. Schober, A.M. Parfitt, Effects of different regimens of sodium fluoride treatment for osteoporosis on the structure, remodeling and mineralization of bone, Osteoporosis Int. 8 (5) (1998) 428-435.

[4] J.Y. Reginster, L. Meurmans, B. Zegels, L.C. Rovati, H.W. Minne, G. Giacovelli, A.N. Taquet, I. Setnikar, J. Collette, C. Gosset, The effect of sodium monofluorophosphate plus calcium on vertebral fracture rate in postmenopausal women with moderate osteoporosis. A randomized, controlled trial, Ann. Intern. Med. 129 (1) (1998) 1-8.

[5] D. Haguenauer, V. Welch, B. Shea, P. Tugwell, J.D. Adachi, G. Wells, Fluoride for the treatment of postmenopausal osteoporotic fractures: a meta-analysis, Osteoporosis Int. 11 (9) (2000) 727-738.

[6] M.A. Buzalaf, G.M. Whitford, Fluoride metabolism, Monogr. Oral Sci. 22 (2011) 20-36.

[7] K.H. Lau, D.J. Baylink, Molecular mechanism of action of fluoride on bone cells, J. Bone Miner. Res. 13 (11) (1998) 1660-1667.

[8] L.R. Brun, L.I. Pera, A. Rigalli, Bone morphometry and differences in bone fluorine containing compounds in rats treated with NaF and MFP, Biomed. Pharmacother. 64 (1) (2010) 1-6.

[9] E.T. Everett, Fluoride's effects on the formation of teeth and bones, and the influence of genetics, J. Dent. Res. 90 (5) (2011) 552-560.

[10] P.T. Cheng, S.M. Bader, D.M. Grynpas, Biphasic sodium fluoride effects on bone and bone mineral: a review, Cell Mater. 5 (3) (1995) 271-282.

[11] H. Qu, M. Wei, The effect of fluoride contents in fluoridated hydroxyapatite on osteoblast behavior, Acta Biomater. 2 (1) (2006) 113-119.

[12] W.G. Beamer, L.R. Donahue, C.J. Rosen, D.J. Baylink, Genetic variability in adult bone density among inbred strains of mice, Bone 18 (5) (1996) 397-403.

[13] M.H. Sheng, K.H. Lau, W.G. Beamer, D.J. Baylink, J.E. Wergedal, In vivo and in vitro evidence that the high osteoblastic activity in $\mathrm{C} 3 \mathrm{H} / \mathrm{HeJ}$ mice compared to C57BL/6J mice is intrinsic to bone cells, Bone 35 (3) (2004) 711-719.

[14] M.H. Sheng, K.H. Lau, S. Mohan, D.J. Baylink, J.E. Wergedal, High osteoblastic activity in $\mathrm{C} 3 \mathrm{H} / \mathrm{HeJ}$ mice compared to $\mathrm{C} 57 \mathrm{BL} / 6 \mathrm{~J}$ mice is associated with low apoptosis in C3H/HeJ osteoblasts, Calcif. Tissue Int. 78 (5) (2006) 293-301.

[15] M.S. Fernandes, M.M. Yanai, G.M. Martins, F.G. Iano, A.L. Leite, T.M. Cestari, R. Taga, M.A. Buzalaf, R.C. de Oliveira, Effects of fluoride in bone repair: an evaluation of RANKL, OPG and TRAP expression, Odontology 102 (1) (2014) 22-30.

[16] A.E. Vieira, C.E. Repeke, S. Ferreira Junior, B. de, P.M. Colavite, C.C. Biguetti, R.C. Oliveira, G.F. Assis, R. Taga, A.P. Trombone, G.P. Garlet, Intramembranous bone healing process subsequent to tooth extraction in mice: micro-computed tomography, histomorphometric and molecular characterization, PLoS One 10 (5) (2015) e0128021.

[17] S.S. Matsuda, T.L. Silva, M.A. Buzalaf, A.C. Rodrigues, R.C. de Oliveira, Differential effects of fluoride during osteoblasts mineralization in C57BL/6J and $\mathrm{C} 3 \mathrm{H} / \mathrm{HeJ}$ inbred strains of mice, Biol. Trace Elem. Res. 161 (1) (2014) $123-129$.

[18] T. Okamoto, M.C. de Russo, Wound healing following tooth extraction. Histochemical study in rats, Rev. Fac. Odontol. Aracatuba 2 (2) (1973) 153-169.

[19] R.C. Oliveira, F.H. Oliveira, T.M. Cestari, R. Taga, J.M. Granjeiro, Morphometric evaluation of the repair of critical-size defects using demineralized bovine 
bone and autogenous bone grafts in rat calvaria, Clin. Oral Implants Res. 19 (8) (2008) 749-754.

[20] T. Accorsi-Mendonca, R.B. Paiva, W.F. Zambuzzi, T.M. Cestari, V.S. Lara, M.C. Sogayar, R. Taga, J.M. Granjeiro, Expression of matrix metalloproteinases-2 and -9 and RECK during alveolar bone regeneration in rat, J. Mol. Histol. 39 (2) (2008) 201-208.

[21] A.J. Dunipace, E.J. Brizendine, W. Zhang, M.E. Wilson, L.L. Miller, B.P. Katz, J.M. Warrick, G.K. Stookey, Effect of aging on animal response to chronic fluoride exposure, J. Dent. Res. 74 (1) (1995) 358-368.

[22] M.A. Buzalaf, C.M. Moraes, K.P. Olympio, J.P. Pessan, L.T. Grizzo, T.L. Silva, A.C Magalhães, R.C. Oliveira, S. Groisman, I. Ramires, Seven years of external control of fluoride levels in the public water supply in Bauru, São Paulo, Brazil, J. Appl. Oral Sci. 21 (1) (2013) 92-98.

[23] S.C. Grubb, T.P. Maddatu, C.J. Bult, M.A. Bogue, Mouse phenome database, Nucleic Acids Res. 37 (Database issue) (2009) D720-D730.

[24] H. Sato, Y. Takeda, Proliferative activity, apoptosis, and histogenesis in the early stages of rat tooth extraction wound healing, Cells Tissues Organs 186 (2) (2007) 104-111.

[25] S. Judex, L.R. Donahue, C. Rubin, Genetic predisposition to low bone mass is paralleled by an enhanced sensitivity to signals anabolic to the skeleton, FASEB J. 16 (10) (2002) 1280-1282.

[26] M.A. Rubin, J. Rubin, I. Jasiuk, SEM and TEM study of the hierarchical structure of C57BL/6J and C3H/HeJ mice trabecular bone, Bone 35 (1) (2004) 11-20.

[27] S.L. Poliachik, D. Threet, S. Srinivasan, T.S. Gross, 32 wk old C $3 \mathrm{H} / \mathrm{HeJ}$ mice actively respond to mechanical loading, Bone 42 (4) (2008) 653-659.

[28] M. Mousny, S. Omelon, L. Wise, E.T. Everett, M. Dumitriu, D.P. Holmyard, X. Banse, J.P. Devogelaer, M.D. Grynpas, Fluoride effects on bone formation and mineralization are influenced by genetics, Bone 43 (6) (2008) 1067-1074

[29] C.P. Puranik, K.A. Ryan, Z. Yin, E.A. Martinez-Mier, J.S. Preisser, E.T. Everett, Fluoride modulates parathyroid hormone secretion in vivo and in vitro, Cells Tissues Organs 200 (6) (2015) 413-423.

[30] J.G. Carvalho, A.L. Leite, D. Yan, E.T. Everett, G.M. Whitford, M.A. Buzalaf, Influence of genetic background on fluoride metabolism in mice, J. Dent. Res. 88 (11) (2009) 1054-1058.

[31] E.T. Everett, M.A. McHenry, N. Reynolds, H. Eggertsson, J. Sullivan, C. Kantmann, E.A. Martinez-Mier, J.M. Warrick, G.K. Stookey, Dental fluorosis: variability among different inbred mouse strains, J. Dent. Res. 81 (11) (2002) 794-798.
[32] F.G. Iano, M.C. Ferreira, G.B. Quaggio, F.S. Fernandes, R.C. Oliveira, V.F. Ximenes, M.A.R. Buzalaf, Effects of chronic fluoride intake on the antioxidant systems of the liver and kidney in rats, J. Fluorine Chem. 168 (December) (2014) 212-217.

[33] M.A. Buzalaf, E.E. Caroselli, J.G. Carvalho, R.C. Oliveira, V.E. Silva Cardoso, J.M. Whitford, Bone surface and whole bone as biomarkers for acute fluoride exposure, J. Anal. Toxicol. 29 (8) (2005) 810-813.

[34] J.G. Carvalho, T.M. Cestari, R.C. Oliveira, M.A. Buzalaf, Fluoride effects on ectopic bone formation in young and old rats, Methods Find. Exp. Clin. Pharmacol. 30 (4) (2008) 287-294.

[35] A.L. Leite, E.E. Caroselli, A.G. Maria, M.S. Fernandes, M.A. Buzalaf, Kinetics of fluoride removal from plasma and bone of rats after chronic intake of fluoride, Methods Find. Exp. Clin. Pharmacol. 30 (3) (2008) 209-214.

[36] C.D. Rubin, C.Y. Pak, B. Adams-Huet, H.K. Genant, J. Li, D.S. Rao, Sustained-release sodium fluoride in the treatment of the elderly with established osteoporosis, Arch. Intern. Med. 161 (19) (2001) 2325-2333.

[37] B.L. Fina, M. Lombarte, J.P. Rigalli, A. Rigalli, Fluoride increases superoxide production and impairs the respiratory chain in ROS 17/2.8 osteoblastic cells, PLoS One 9 (6) (2014) e100768.

[38] Y. Wei, Y. Wu, B. Zeng, H. Zhang, Effects of sodium fluoride treatment in vitro on cell proliferation, BMP-2 and BMP-3 expression in human osteosarcoma MG-63 cells, Biol. Trace Elem. Res. 162 (1-3) (2014) 18-25.

[39] Q. Liu, H. Liu, X. Yu, Y. Wang, C. Yang, H. Xu, Analysis of the role of insulin signaling in bone turnover induced by fluoride, Biol. Trace Elem. Res. 171 (2) (2016) 380-390.

[40] X. Yan, X. Hao, Q. Nie, C. Feng, H. Wang, Z. Sun, R. Niu, J. Wang, Effects of fluoride on the ultrastructure and expression of Type I collagen in rat hard tissue, Chemosphere 128 (2015) 36-41.

[41] D. Yan, A. Gurumurthy, M. Wright, T.W. Pfeiler, E.G. Loboa, E.T. Everett, Genetic background influences fluoride's effects on osteoclastogenesis, Bone 41 (6) (2007) 1036-1044.

[42] M.P. Akhter, D.M. Cullen, E.A. Pedersen, D.B. Kimmel, R.R. Recker, Bone response to in vivo mechanical loading in two breeds of mice, Calcif. Tissue Int. 63 (5) (1998) 442-449.

[43] A.G. Robling, C.H. Turner, Mechanotransduction in bone: genetic effects on mechanosensitivity in mice, Bone 31 (5) (2002) 562-569. 